\title{
WILLIAM JAMES E WHITEHEAD SOBRE O MITO DA LACUNA EXPLICATIVA ${ }^{1}$
}

\author{
Arthur Araújo (UFES) \\ aart037@gmail.com
}

Resumo: o artigo apresenta uma releitura do problema da lacuna explicativa partindo do empirismo de William James e Alfred N. Whitehead. Segundo as respectivas noções de experiência e processo de James e Whitehead, o artigo procura mostrar que a lacuna explicativa é um mito filosófico na medida em que sustenta uma continuidade ontológica ao mesmo tempo conjugada com uma descontinuidade epistemológica entre mente e mundo ou mente e cérebro - em particular, como ilustração dessa incongruência entre continuidade e descontinuidade, o núcleo do artigo se concentra em torno da revisão do chamado problema dos qualia. Partindo do empirismo de James e Whitehead, e tendo em vista a noção de continuidade, o artigo indica uma alternativa ao déficit epistemológico da lacuna explicativa assim como à visão internalista de mente que ela inspira - a ideia de que a mente está enclausurada no cérebro. Como resultado, o artigo indica a atualidade do empirismo de James e Whitehead em consonância com as crescentes abordagens não-internalistas de mente e cognição em termos de continuidade que as noções respectivas de James e Whitehead de experiência e processo sugerem.

Palavras-chave: James; Whitehead; Lacuna Explicativa; Mito.

\section{INTRODUÇÃO}

$\mathrm{O}$ artigo é resultado de uma pesquisa sobre William James, já com três bons resultados publicados (ARAUJO 2014/8; ARAUJO 2016; ARAUJO 2018) e uma tradução (ARAUJO 2016). Em sentido amplo, a proposta visa aproximar as respectivas formas de empirismo de William James e Alfred N. Whitehead. ${ }^{3}$ Dessa aproximação, em particular, o objetivo é

\footnotetext{
${ }^{1}$ Recebido em: 01-07-2018/ Aprovado em: 01-07-2019/ Publicado on-line em: 15-08-2019.

${ }^{2}$ Arthur Araújo é Professor da Universidade Federal do Espírito Santo, Vitoria, ES, Brasil.

${ }^{3}$ Sobre o paralelo entre James e Whitehead, entre várias referências, em particular, ver Wahl ([1932] 2004); o clássico de Eisendrath (1971); Weber (2011); e Stenner (2011).
} 
a revisão do chamado problema da 'lacuna explicativa' em filosofia da mente. Considerando o objetivo geral e o particular do artigo, a ideia principal é caracterizar e avançar o empirismo de James e Whitehead como alternativa às visões materialistas tradicionais em filosofia da mente.

Uma parte significativa de filósofos consagrou um argumento que inspirou uma visão particular de mente. Para Joseph Levine, em seu influente artigo Materialism and Qualia: The Explanatory Gap (1983), não exatamente a relação com a mente, mas a relação entre cérebro e consciência é o problema: o conhecimento do cérebro não inclui a consciência e o resultado é uma 'lacuna explicativa' [explanatory gap]. Embora a lacuna explicativa não implique em descontinuidade ontológica, a afirmação de identidades psicofísicas induz um déficit de explicação. Muitos filósofos, como Place, Feigl, Smart e Armstrong, já anteciparam tal perspectiva materialista e Levine sofistica um argumento em torno do qual se desenvolveu parte importante dos debates entre tendências reducionistas e não-reducionistas. Como ponto comum, ambas as tendências partilham uma compreensão internalista de mente relacionada à existência de cérebro, sistema nervoso ou alguma estrutura física semelhante - alguma coisa como 'sem cérebro, sem mente'.

O problema da lacuna explicativa tem certo parentesco histórico com a Revolução Científica de Galileu. Inspirado pelo atomismo de Demócrito, de um lado, e, de outro, pela visão platônica de uma natureza matemática, Galileu cinde as propriedades dos objetos em duas classes (qualidades primárias e secundárias). Mais recentemente, Erwin Schroedinger em Mind and Matter (Chapter 6 - The mystery of the sensual qualities [qualidades secundárias]), que corresponde a um anexo da inigualável What is Life?, também retoma ao princípio do atomismo de Demócrito e igualmente alimenta a 
ideia de lacuna explicativa entre mente e matéria. ${ }^{4}$

Também é curioso notar que parte significativa de filósofos da mente e da ciência não parece ter incorporado a revolução científica resultada dos esquemas conceituais da teoria da relatividade, mecânica quântica ou termodinâmica (sem mencionar a revolução na biologia começada com a teoria da evolução de Darwin). No contexto desse paradigma latente, as noções de não-linearidade, processo, complexidade ou continuidade espaço-temporal dissolvem os princípios da visão de natureza do mecanicismo de Galileu, Descartes e Newton. De modo direto na filosofia de Whitehead e, de modo indireto, para William James, as noções de não-linearidade, processo, complexidade e continuidade espaço-temporal indicam uma compreensão não-mecanicista e não-internalista de mente.

É objetivo do artigo argumentar que a forma de empirismo de James e Whitehead sinaliza uma alternativa à lacuna explicativa e à concepção internalista de mente que ela inspira. Como contextualização do problema da lacuna explicativa, é importante destacar que, no início de Principles of Psychology, James define a 'psicologia' como a 'ciência da vida mental' em termos de fenômenos como 'sentimentos, desejos, cognições, raciocínios, decisões e assim por diante’. Um

\footnotetext{
4 'Existe ostensivamente cor, existe ostensivamente doçura, ostensivamente amargor, e na verdade apenas átomos no vazio [...] Pobre intelecto, esperas derrotar-nos ao mesmo tempo em que tomas de nós tua evidência? Tua vitória é tua derrota' (Demócrito apud SCHROEDINGER 1967, p. 163). Em um tratado epicurista intitulado De signis, Philodemus explicita as propriedades em dois tipos: koinotetai - propriedade comum que pertence a uma entidade da qual não se lhe pode separar sob risco de causar sua destruição e idiotetai - propriedade particular acidental que não afeta a natureza própria dos corpos (MANETTI 2002). A dualidade propriedades primárias e secundárias mostra uma longa raiz histórica que persiste em uma visão essencialista de realidade. No sentido aristotélico, por exemplo, o essencialismo significa a afirmação de que existe uma entidade tal ou substância da qual se predica propriedades essenciais e acidentais. Como fica evidente na forma de empirismo de James e Whitehead, contra o essencialismo, tem lugar um anti-essencialismo ou eventualismo: a primazia ontológica é a relação e não a substância. Como se destacará ao longo do artigo, o antiessencialismo é um componente importante de compreensão dos qualia segundo a forma de empirismo de James e Whitehead.

Cont.
} 
parágrafo abaixo, James mostra estar ciente do limite de explicação mecanicista dos fenômenos mentais e que, de modo particular, me parece ilustrar o problema da lacuna explicativa e a recusa ao internalismo em filosofia da mente. ${ }^{5}$

Como primeiro passo de desenvolvimento do artigo, apresento e situo contextualmente a lacuna explicativa e em que sentido ela representa um mito filosófico. Como passo seguinte, procuro aproximar as respectivas noções de experiência e processo de James e Whitehead. Da parte de James, as referências principais são Essays on Radical Empiricism ([1909] 1977) e The Pluralistic Universe (1909); e da parte de Whitehead, Process and Realitly ([1929] 1978). Seguindo tais referências, procuro mostrar a sintonia entre as noções de experiência, processo e continuidade que balizam a forma de empirismo desenvolvida por James e Whitehead. Como terceiro passo, exploro as possíveis referências de ambos os filósofos que dissipam a lacuna explicativa como mito filosófico. ${ }^{6}$ Também nessa parte do artigo, traço um paralelo entre o empirismo de James e Whitehead e as abordagens não-internalistas de mente e cognição em filosofia da mente e ciências cognitivas

$\mathrm{Na}$ parte final do artigo, estará em relevo a revisão do significado dos qualia em comparação com contextos filosóficos tradicionais. Também derivada do empirismo de James e Whitehead, o artigo conclui com uma proposta de dissolução da lacuna explicativa apontando uma visão não-internalista de mente segundo as noções de experiência e processo. Embora a existência de cérebro ou sistema nervoso seja parte

\footnotetext{
5 'When, for instance, I recall my graduation-day, and drag all its incidents and emotions up from death's dateless night, no mechanical cause can explain this process, nor can any analysis reduce it to lower terms or make its nature seem other than an ultimate datum, which, whether we rebel or not at its mysteriousness, must simply be taken for granted if we are to psychologize at all' (JAMES [1980] 1952, p. 1).

${ }^{6}$ É importante sublinhar que estou usado 'mito' em sentido derivado de 'mito de Descartes' ou ‘fantasma na máquina' (RYLE [1949] 2009).
} 
da explicação da noção de mente, somente ela não é suficiente. A ideia é que a compreensão de mente seja melhor situada em função do caráter de externalidade e continuidade que as noções de experiência e processo sugerem.

\section{ESTRUTURA E MITO DA LACUNA EXPLICATIVA}

Joseph Levine (1983) cria a expressão 'lacuna explicativa' em seu influente artigo Materialism and Qualia: The Explanatory Gap. Embora a lacuna explicativa não implique descontinuidade ontológica, ela significa que alguma coisa não encontra explicação quando se tenta representar o mental em termos de identidades psicofísicas. Levine (1983 p. 354/357) afirma que nada se explica das propriedades qualitativas da experiência de dor assumindo a identidade psicofísica 'dor é ativação das fibras-C' (ou qualia). ${ }^{7}$ Uma parte do conceito de dor explica nossas experiências e relações com o mundo e não significa 'ativação das fibras-C' ${ }^{8}$ Como consequência dessa disjunção conceitual, o resultado é uma lacuna explicativa como descontinuidade epistemológica entre mental e físico:

[...] I think it supports a closely related epistemological thesis namely, that psycho-physical identity statements leave a significant explanatory gap, and, as corollary, that we don't have any way of determining exactly which psycho-physical identity statement are true (LEVINE, 1983, p. 354).

Então, conclui Levine (1983, p. 360), enquanto a

\footnotetext{
${ }^{7}$ Clarence I. Lewis, ex-aluno de William James, define precisamente o significado de qualia (singular, quale): [qualia] 'must be distinguished from the properties of objects [...] The quale is directly intuited, given, and it is not the subject of any possible error because it is purely subjective [...] The real roundness of the real penny is seen as all degrees of elliptical appearance [...] But, the giveness of the appearance is not the giveness of objective roundness [...] the same quale may be, for correct interpretation, the sign of different objective properties and different qualia may be the sign for the same objective property [...] Qualia are subjective; they have no name in ordinary discourse but are indicated by some circumlocution such as "look like"; they are ineffable' (LEWIS [1929] 1990, p. $121-2 / 124)$.

${ }^{8} \mathrm{O}$ exemplo das fibras-C está no próprio artigo de Levine.
} 
identidade psicofísica é metafisicamente factual, é epistemologicamente implausível. Se assumidas as identidades psicofísicas, os conteúdos fenomenais da experiência (qualia) não parecem ser idênticos à descrição das propriedades físicas do cérebro (LEVINE 1983, p. 357). As afirmações 'dor é ativação das Fibras-C' e 'dor é uma experiência' não implicam que 'experiência de dor' seja 'ativação das Fibras-C'. De modo similar, filósofos como Jackson (1982), Nagel (1974) e Chalmers (1996) procuraram mostrar que o conhecimento objetivo do cérebro não inclui a perspectiva subjetiva da experiência e, com efeito, reforçaram o argumento de descontinuidade epistemológica.

Anterior e posteriormente ao artigo de Levine, parte significativa da filosofia da mente se desenvolveu oscilando entre interpretações reducionistas e não-reducionistas das identidades psicofísicas. Do lado reducionista, sustenta-se a identidade de tipo [types] de estados mentais e físicos do cérebro; do lado não-reducionista, sustenta-se que a identidade de caso [tokens] descreve um único e particular estado físico. A diferença é que a identidade de caso é mais fraca e, consequentemente, atenua o grau de determinação ontológica. A identidade de caso é também compatível com as formas tradicionais de funcionalismo que atraiu um número expressivo de filósofos da mente.

O significado da lacuna explicativa não é tanto a originalidade. ${ }^{9} \mathrm{O}$ que se mostra na controvérsia gerada por ela é a aceitação por muitos filósofos de formas de reducionismo e

\footnotetext{
${ }^{9}$ In Psychology in Physical Language (1932), Rudolf Carnap introduz uma forma dura de fisicalismo que tende a eliminar a lacuna explicativa. Para ele: 'every psychological statement can be translated into statements of a physical language that are about someone's physical states' (CARNAP 1932, p. 39). Se, nos termos de Levine, $X$ é um conceito psicológico (por exemplo, 'dor'), e Y é um conceito físico (por exemplo, 'ativação das fibras-C), que traduz o primeiro, pode-se verificar epistemologicamente o significado de X. O fisicalismo de Carnap elimina a descontinuidade epistemológica derivada da lacuna explicativa. Segundo Carnap (1932, p. 32), uma asserção física que traduz uma asserção mental é intersubjetiva.
} 
não-reducionismo. De um lado, o problema mente-cérebro pode ser compreendido em causação mental e consciência. A interação entre eventos mentais e físicos não parece controversa se a eficácia causal entre eles é considerada física. É o chamado 'problema fácil' [easy problem] de Chalmers (1996). De outro, no entanto, a consciência não parece implicar simplesmente causalidade física como explicação. É o que Chalmers (1996) chama de 'problema difícil' [hard problem]. Quanto à distinção entre tipos de consciência, atribuem-se, respectivamente a elas, intencionalidade e qualia: enquanto a intencionalidade corresponde a uma propriedade representacional, qualia são não-representacional. Além de imune a uma caracterização representacional, qualia carecem de explicação em termos de causalidade física e funcional e seriam o exemplar característico do problema difícil

Por que a lacuna explicativa é um mito filosófico? Mito é um tipo de estrutura explicativa de fatos e fenômenos da qual se visa transmitir conhecimento como representação de uma visão de mundo (BARTHES, 1982, p. 131). Como mito é quase sempre um tipo de estrutura explicativa que rompe o princípio de continuidade, ele induz à descontinuidade sobre a rede causal de eventos do mundo. Quando Levine afirma que a expressão 'lacuna explicativa' significa que há alguma coisa inexplicada com as identidades psicofísicas, e ao mesmo tempo assume que elas são metafisicamente plausíveis, é evidente a descontinuidade como rompimento da rede causal de explicação dos eventos do mundo. O resultado desse rompimento gera a matriz que alimenta a lacuna explicativa como mito filosófico. Um mito que se expressa nos termos da crítica de Ryle ([1949] 2009, p. 12) à crença de que mente e cérebro são de mesmo tipo lógico: se o cérebro é alguma coisa, a mente também deve ser.

Segundo Hutto e Myn (2013, p. 169), contudo, uma 
forma atenuada de materialismo aceitaria a lacuna explicativa. Mas qual é a virtude filosófica em se aceitar a continuidade ontológica e ao mesmo tempo assumir uma descontinuidade epistemológica entre mental e físico? A resposta óbvia parece ser o avatar do cartesianismo em forma de materialismo. Quando se afirma a lacuna explicativa e ao mesmo tempo se sustenta a continuidade ontológica entre mental e físico, a narrativa materialista perde de vista a rede causal de explicação dos eventos do mundo. Talvez o caso extremo dessa narrativa seja representado pelo 'monismo anômalo' de Donald Davidson (1980, p. 208): embora compartilhem uma mesma ontologia físicalista, estados mentais não podem ser fisicamente explicados.

A lacuna explicativa parece um problema porque se assume o significado de mente segundo uma visão internalista: 'mente' deve ser alguma coisa dentro do cérebro. Como revisão da lacuna explicativa, vou aproximar as respectivas formas de empirismo de James e Whitehead. Deve ficar claro que não se trata de uma sobreposição de ideias entre ambos os filósofos. A aproximação procura evidenciar a compatibilidade de uma visão de mente em que as noções de experiência e processo sejam tomadas como fundamentais e indicar uma abordagem além da clausura do cérebro.

\section{EXPERIÊNCIA, PROCESSO, EMPIRISMO}

Nesta parte do artigo, de James, destaco a noção de 'experiência' em seu Essays on Radical Empiricism ([1909] 1977) e a visão pluralista de mundo em The Pluralistic Universe (1909). Ambas as referências mostram que a experiência tem uma estrutura contínua em oposição ao dualismo mente-mundo ou mente-corpo. Da parte de Whitehead, fundamentalmente, exploro a noção de 'processo' em sua obra máxima 
Process and Realitly ([1929] 1978). No prefácio dessa obra, além de Bergson e Dewey, Whitehead ([1929] 1978, p. xii) reconhece a influência de James. Seguindo também o princípio heraclitiano do $\pi \alpha ́ v \tau \alpha \dot{\rho} \varepsilon \tilde{\mathbf{u}}$, para Whitehead, a noção de processo se opõe à estrutura estática do ser e à metafísica tradicional da substância: processo é a premissa que sustenta a compreensão da realidade como um contínuo em constante transformação. ${ }^{10}$

Conjugadas as noções de experiência e processo, elas sintetizam uma forma de pensamento da qual Whitehead amplia o empirismo de James (STENNER 2011, p. 101). Para muitos críticos, tal forma de empirismo soa como idealismo. No entanto, creio, ela significa uma forma de panexperimentalismo que acentua a aproximação entre as noções de experiência e processo (JAMES [1895] 1977, p. 154)" ${ }^{11}$ Em um contexto atual em filosofia da mente, 'panexperimentalismo' é também designado 'panpsiquismo' (CHALMERS 2017 p. 19). Por mais estranho que pareça, para muitos filósofos da mente, o panpsiquismo oferece uma abordagem da mentalidade humana e não-humana conforme uma concepção unificada de natureza. A ideia é que a mentalidade seja entendida como uma propriedade distribuída no mundo natural e que não implica a aceitação de que todas as coisas

\footnotetext{
10 'THAT 'all things flow' is the first vague generalization which the unsystematized, barely analysed, intuition of men has produced [...] it appears as one of the first generalizations of Greek philosophy in the form of the saying of Heraclitus [...] the flux of things is one ultimate generalization around which we must weave our philosophical system [...] At this point we have transformed the phrase, 'all things flow', into the alternative phrase, 'the flux of things'. In so doing, the notion of the 'flux' has been held up before our thoughts as one primary notion for further analysis' (WHITEHEAD [1929] 1978, p. 208).

11 'Panexperimentalism' [suggests] 'that the ultimate building blocks of reality are drops of experience, not tiny billard balls or little hard things totally devoid of feeling as modern materialist worldviews usually suppose' (MESLE 2008, p. 93; WEBER 1999, p. 92). Panexperimentalismo também qualifica o que eventualmente se designa 'pensamento do processo'. Ao lado de James e Whitehead, estão nomes como Henri Bergson, Samuel Alexander, Charles Peirce e John Dewey (TEIXEIRA 2011, p. 14) [e também Kitaro Nishida].

Cont.
} 
materiais tenham uma mente (como, por exemplo, pedras). O problema é que as tentativas de impulsionar o panpsiquismo usualmente partem de uma premissa internalista em torno do problema mente-cérebro: tal premissa representa a suposição de que os fatos mentais são fundados, realizados ou constituídos sobre fatos em micro-níveis do cérebro (CHALMERS 2017 p. 25). ${ }^{12}$

Seguindo o empirismo de James e Whitehead, não precisamos temer o panpsiquismo. Ele pode ser reformulado fora de bases internalistas assumindo o caráter ontológico e epistêmico da experiência como processo e estrutura derivativa do conhecimento. ${ }^{13}$ Como forma de empirismo, panexperimentalismo indica a radicalização do caráter de eventualidade da experiência em oposição à ideia de realidade cindida em aspectos internos e externos. Tendo em relevo a noção de eventualidade, segundo James, o que importa essencialmente é que os aspectos da realidade sejam eles mesmos elementos experenciáveis e experenciados. Assim, como tudo o que existe se deriva da experiência, perde sentido a visão de cisão da realidade entre propriedades extensas e não-experenciáveis, de um lado, e, de outro, propriedades não-extensas e experenciáveis (ou propriedades primárias e secundárias). Tal visão de cisão não está distante da descontinuidade epistemológica derivada da lacuna explicativa. Segundo o panexperimentalismo que ilustra a forma do empirismo de James e Whitehead, a noção de que a realidade se traduz por eventualidade da experiência sugere um

\footnotetext{
${ }^{12}$ Sobre história e contexto atual do panpsiquismo, cf. https://plato.stanford.edu/entries/panpsychism/.

${ }^{13}$ The subjectivist principle is that the whole universe consists of elements disclosed in the analysis of the experiences of subjects. Process is the becoming of experience. It follows that ... the philosophy of organism also accepts Hume's doctrine that nothing is to be received into the philosophical scheme which is not discoverable as an element in subjective experience. This is the ontological principle (Whitehead, [1929] 1978, p. 166).

Cont.
} 
construtivismo epistemológico anti-fundacionalista em que se evidencia a relevância da noção de continuidade. ${ }^{14}$

É importante ressaltar que a matriz filosófica do panexperimentalismo de James e Whitehead atualiza o empirismo de Berkeley. Ambos se referem a Berkeley com distinção e não somente por causa da crítica à noção de matéria. Segundo o empirismo de Berkeley, não há descontinuidade entre as sensações e os objetos sensivelmente apreendidos (cf. nota 27). De fato, contra o materialismo, James e Whitehead negam que a matéria seja a realidade última da qual se deriva nossa concepção de mente - tudo que se pode conceber da realidade mental se deriva de relações experenciadas. Segundo James ([1905] 1977, p. 186), as sensações não são duplicações internas das coisas e elas são o que elas mostram na experiência; por sua vez, segundo Whitehead (1948, p. 71), o processo de preensão substituiria a 'mente' de Berkeley.

'Preensão' [prehension] é um termo geral usado por Whitehead que designa um 'ativo vir junto' [active coming together]. Ele emprega 'preensão' antes de Process and Reality em Science and Modern World:

The word perceive is, in our common usage, shot through and through with the notion of cognitive apprehension. So it is the word apprehension, even with the adjective cognitive omitted. I will use the word prehension for uncognitive apprehension: by this I mean apprehension which may or may not be cognitive (WHITEHEAD [1925] 1948, p. 70).

Como instanciação de uma unidade preensitiva:

In the genetic theory, the cell is exhibited as appropriating for the

\footnotetext{
${ }^{14}$ Em especial, se destaca aqui uma forma de empirismo proposta por Wilfrid Sellars em filosofia da mente como crítica às teorias dos dados dos sentidos. Conforme tais perspectivas, ter consciência de certos objetos é ter dados dos sentidos da experiência: compondo a estrutura do dado, de um lado, está o ato de consciência e, de outro, está o objeto correspondente ao ato (SELLARS [1956] 1997 , p. 14; 62). De modo particular, a crítica de Sellars ao 'mito do dado' mostra afinidade com o empirismo de James e Whitehead na medida em que nega a duplicação interna da experiência.
} 
foundation of its own existence, the various elements of the universe out of which it arises. Each process of appropriation of a particular element is termed a prehension. The ultimate elements of the universe, thus appropriated, are the already constituted actual entities (WHITEHEAD [1929] 1978, p. 219).

Empregando o termo preensão, como James, Whitehead procura explicitar uma perspectiva essencialmente anti-intelecutualista e anti-representacionalista de mente e cognição - não por acaso, Whitehead ilustra o comportamento celular como um tipo de atividade preensitiva. Embora ele reconheça o paralelo com o uso de Leibniz de 'percepção' e 'apercepção' com respeito às mônadas, Whitehead sublinha que esses termos estão intimamente relacionados com as noções de percepção representativa e consciência que ele nega ${ }^{15}$.

No seu clássico estudo sobre James e Whitehead, Eisendrath (1971, p. 40-1) mostra que ambos os filósofos não compreendem a experiência como uma séria estática de tomadas da realidade que a mente ordenaria em representações ${ }^{16}$. O que Eisendrath (1971, p. 43) designa 'momento unificante' [unifying moment] representa uma concepção de continuidade da experiência que rompe com as formas tradicionais de dualismo e materialismo. Como James desenvolve no capítulo The Stream of Thought (The Principles of Psychology, [1890] 1952), a noção de 'fluxo' [stream] representa um forte componente sobre a concepção de processo de Whitehead. Aliás, James é creditado por ter sido talvez o primeiro a usar a noção de processo em relação à vida mental (MCDERMOTT 1977, p. xxxv - nota 39). Em Science and The Modern World (1948, p. 143), Whitehead reconhece que

\footnotetext{
${ }^{15}$ This is a theory of monads; but it differs from Leibniz's in [...] In the organic theory, they merely become. Each monadic creature is a mode of the process of 'feeling' the world, of housing the world in one unit of complex feeling, in every way determinate (WHITEHEAD [1929] 1978, p. 80).

16 'We may express this also by stating that experience is not a function of mind or consciousness, but that mind and consciousness are rather products of experience' (HAYEK 1952, p. 165-6).

Cont.
} 
James supera a visão dualista de mente como um tipo de container discreto e separado do mundo. Contra uma visão atomística de mente, James evoca a imagem holista do mosaico e que ilustra a característica essencial do empirismo que ele desenvolve. ${ }^{17}$

Dessa imagem holista, a noção de 'continuidade' ganha um significado fundamental nas respectivas concepções de experiência e processo de James e Whitehead. Enquanto, para James ([1890] 1952, p. 318), a experiência apresenta objetos contínuos com o mundo incorporados por ela; para Whitehead ([1929] 1978, p. 66) no capítulo The extensive continuum, o contínuo é um complexo de entidades unidas por um processo dinâmico da parte ao todo. Assim, o empirismo de James e Whitehead pode ser resumido nos seguintes termos: nada existe no mundo, que não seja parte de um continuum da experiência, tem significado de realidade ou pode ser conhecido ${ }^{18}$. Aqui, em particular, se destaca um elemento importante na epistemologia de James em The knowing of things together ([1895] 1977) que indica uma concepção relacional e externalista de conhecimento: o 'visar' do pensamento ao mundo é uma 'operação externa e acidental' em que as coisas são conhecidas em continuidade (JAMES [1895] 1977, p. 155). Como James, Whitehead insiste sobre a relevância epistemológica da continuidade ao se explicar o conhecimento e sua relação com a mente.

\footnotetext{
17 'My description of things, accordingly, starts with the parts and makes of the whole a being of second order. It is essentially a mosaic philosophy, a philosophy of plural facts' (JAMES [1904] 1977, p. 195).

18 'To be radical, an empiricism must neither admit into its constructions any element that is not directly experienced, nor exclude from them any element that is directly experienced [...] the relations that connect experiences must themselves be experienced relations, and any kind of relation experienced must be accounted as 'real' as anything else in the system' (James [1904] 2000, p. 315). Em comparação, para Whitehead: 'Finally, the reformed subjectivist principle must be repeated: that apart from the experiences of subjects there is nothing, nothing, nothing, bare nothingness' (WHITEHEAD [1929] 1978, p. 167).

Cont.
} 
Incorporada a noção de continuidade, já se esboça uma alternativa de dissolução da lacuna explicativa: o conhecimento da mente se afirma em continuidade com o mundo e o conhecimento do mundo se afirma em continuidade com a mente - para James, é o caso de continuidade da experiência; para Whitehead, é a continuidade do processo ${ }^{19}$. Ambas as afirmações dissipam o pressuposto de descontinuidade epistemológica da lacuna explicativa assim como dissipam também a visão internalista de mente que ela infunde. Em particular, a ideia de continuidade epistemológica mostra sintonia com as recentes abordagens chamadas cognição incorporada: a ideia de que uma rede de interações entre organismo e meio é gradualmente transformada em formas conceituais - é o que, por exemplo, James designa a continuidade entre perceptos e conceitos. ${ }^{20}$

Tendo em vista a ideia de continuidade, como Putnam assinala (1995, p. 7; 13), o holismo é uma característica da filosofia da James em oposição a dualismos familiares como, por exemplo, fato e valor. Também como assinala Putnam (1995), o chamado 'realismo direto' é uma característica da filosofia da James: a percepção de objetos e eventos está (normalmente) "lá fora" e não [corresponde] a dados dos sentidos privados. Antes de serem inconsistentes, segundo Putnam, holismo e realismo direto são interdependentes. Uma ideia que também não parece estranha à noção de Whitehead de processo. Muitos processos naturais têm certo grau de valor

\footnotetext{
19 'Experience is a process that continually gives us new material to digest. We handle this intellectually by the mass of beliefs of which we find ourselves already possessed, assimilating, rejecting or rearranging in different degrees' (JAMES, [1904] 1978, p. 208).

${ }^{20}$ The great difference between percepts and concepts is that percepts are continuous and concepts are discrete. Not discrete in their being, for conception as an act is part of the flux of feeling, but discrete from each other in their several meanings. Each concept means just what it singly means, and nothing else [...] The perceptual flux as such, on the contrary, means nothing (JAMES 1916, p. 48-9)
} 
e normatividade. Em contextos de cognição incorporada, por exemplo, admite-se que muitos processos dependem de uma variedade de processos particulares cujo resultado é uma totalidade funcional - cada processo particular é funcional para a ocorrência do processo total. É uma compreensão de processo muito próxima à ontologia do processo desenvolvida por Wilfrid Sellars.

Sellars mostra que uma ontologia do processo implica uma concepção nominalista de propriedades; e que, por exemplo, aceitaria o panexperimentalismo de James e Whitehead:

75. The claim that it is events, rather than things, which are primary. 103. The idea has fascinating implications. Indeed, we have in barest outline a truly heracleitean ontology panta rei. There are no objects. The world is an ongoing tissue of goings on (SELLARS 1981)

Como premissa nominalista e seguindo a ontologia heraclitiana, para Sellars, o que define propriedade é relação e não a forma de predicação objeto e atributo. Assim, argumenta ele, qualia devem ser entendidos como aspectos de processos. Uma ideia que coincide com James e Whitehead em que as sensações são elementos contínuos com a experiência e não entidades mentais discretas ${ }^{21}$. Como aspectos de processo, qualia são categorizados de modo relacional ou adverbial $^{22}$. Segundo essa interpretação dos qualia, desde conteúdos sensoriais elementares, como, por exemplo, é o caso de bactérias, a conteúdos normativos de experiências conceituais, um conteúdo não é nada senão um modo de funcionamento. Para Sellars, assim como para James e Whitehead,

\footnotetext{
${ }^{21} 124$. What is required is an account of this continuity which posits neither instantaneous processes nor (pace Whitehead) processes which are entities such that it is a rock bottom ontological truth that they have a finite duration (SELLARS 1981).

${ }^{22}$ Sellars retoma uma tese adverbialista desenvolvida anteriormente: 'P Adv V: where 'Adv' represents 'a red rectangle' construed as an adverbial phrase, and ' $\mathrm{V}$ ' represents 'senses' construed as an intransitive verb' (SELLARS 1979, p. 91-2).
} 
um conteúdo é uma função. Não é função no sentido em que filósofos da mente e cientistas cognitivos funcionalistas entendem ser uma função a realização de mecanismos estáticos de input-output. Sellars desenvolve uma concepção processualista de função baseada em uma naturalização que descreve diferentes graus de normatividade. ${ }^{23}$ Perde sentido a dualidade entre fato e norma uma vez que muitos processos naturais realizam certa forma de normatividade. A ideia é que a normatividade não pode ser deduzida de esquema abstratos de pensamento e envolveria também formas elementares de comportamento (por exemplo, bactérias ou unidades celulares). Na medida em que normas são processos funcionais (e não representações abstratas que descrevem condutas comportamentais), elas indicam diferentes níveis de realização.

A ontologia do processo desenvolvida por Sellars mostra um paralelo com o princípio ontológico de Whitehead. ${ }^{24}$ Ela também evidencia aspectos holista e realista que coincidem com a crítica de James ao dualismo entre fato e norma. Como consequência dessa ontologia, fica patente que os significados de mente ou cognição não estão restritos à descrição da existência de cérebro ou sistema nervoso ('sem cérebro, sem mente, sem cognição'). A ideia é muito mais que mente e cognição sejam compreendidas como processos e graus de organização do que como realidade interna do

\footnotetext{
${ }^{23}$ Em sentido próximo, Terrence Deacon também entende função como realização de processo: [...] the various actions and processes typically employed to achieve [a] goal function for the sake of it. Finally, the success or failure to achieve [a] goal has value because it is in some way relevant to the agency for the sake of which it is pursued. And all these features are contributors to the sentience of simple organisms and the conscious experience of thinking beings like ourselves (DEACON 2012, p. 25).

24 'The ontological principle [...] constitutes the first step in the description of the universe as a solidarity of many actual entities. Each actual entity is conceived as an act of experience arising out of data. It is a process of 'feeling' [...] Here 'feeling' is the term used for the basic generic operation of passing from the objectivity of the data to the subjectivity of the actual entity in question' (WHITEHEAD [1929] 1978, p. 40).

Cont.
} 
cérebro - muitas designações representam essa concepção alternativa de mente e cognição como 'mente estendida', 'cognição incorporada' ou 'continuidade mente e vida'25.

Retomando a lacuna explicativa, nos termos em que ela é apresentada, de fato, representa um problema epistemológico incontornável. Uma alternativa possível talvez seja a mudança de perspectiva filosófica: avançar além das tentativas de explicar conteúdos mentais em termos de correlações estritas com o cérebro e incluir a ideia de continuidade. Uma tal alternativa filosófica não está isolada e conta com um importante precedente. Francisco Varela (et al., 1999, p. 18) sugere a integração entre os dados fenomenológicos da experiência (por exemplo, qualia) e a descrição objetiva dos processos cognitivos. O resultado é a circulação, aqui entendida como continuidade, entre experiência e descrição que preencheria o déficit epistemológico da lacuna explicativa.

\section{EXPERIÊNCIA E PROCESSO: BACKGROUND DA COGNIÇÃO INCORPORADA}

Nesta parte do artigo, traço um paralelo entre o empirismo de James e Whitehead e a perspectiva de cognição incorporada em filosofia da mente e ciências cognitivas. $\mathrm{O}$ paralelo também acentua o significado da lacuna explicativa como mito filosófico. Ser um mito filosófico não é um demérito da lacuna explicativa. Assim como os mitos nutrem o imaginário coletivo e são importantes narrativas de explicação e transmissão de conhecimento do mundo, a lacuna

\footnotetext{
${ }^{25}$ What we call 'mind' is thus a particular order of a set of events taking place in some organism and in some manner related to but not identical with, the physical order of events in the environment. The problem which the existence of mental phenomena raises is therefore how in a part of the physical order (namely an organism) a sub-system can be formed which in some sense (yet to be more fully defined) may be said to reflect some features of the physical order as a whole, and which thereby enables the organism which contains such a partial reproduction of the environmental order to behave appropriately towards its surroundings $[\ldots]$ the mind is a process (HAYEK 1952, p. 16; 169).
} 
explicativa também estimulou uma visão de mente que impulsionou o desenvolvimento de parte significativa da filosofia da mente. Mas assim como a estrutura explicativa dos mitos tem limite, a visão de mente que a lacuna explicativa inspira parece exaurida.

Embora a filosofia da mente tenha tido como matriz a negação do dualismo cartesiano, não se surpreende que uma parte significativa sua tenha tido um desenvolvimento paralelo a ele: a tese de que a mente é um tipo de realidade enclausurada no cérebro. Uma tese que atualizou os Artigos 31 e 32 de As Paixões da Alma de Descartes: é no cérebro (glândula pineal) que a mente (alma) exerce imediatamente suas funções. Como resultado, uma visão internalista de mente oscila entre duas vertentes: do materialismo reducionista, as funções mentais estão identificadas a estados físicos do cérebro; do materialismo não-reducionista, as funções mentais podem ser fisicamente realizadas e, no entanto, não estão identificadas a estados do cérebro (esta é basicamente a tese do funcionalismo tradicional em filosofia da mente).

Em comparação ao empirismo de James e Whitehead, um movimento crítico se desenvolveu contra a visão internalista de cognição a partir da perspectiva enatista aberta por Francisco Varela (1993). Como consequência dessa perspectiva, cognição tem sido situada como processos incorporados, situados, enativos e estendidos ['embodied, embedded, enacted and extended processes or the 4E's theories'] (MENARY 2010, p. 459). ${ }^{26} \mathrm{O}$ objetivo da cognição é conduzir a ação [world-making] e não formar representações internas do

\footnotetext{
${ }^{26}$ No interior das teorias 4'Es, é importante distinguir entre enativismo e extensionalismo: [...] both viewpoints stress the crucial contributions that the body and the environment make to cognition, and recent discussions have emphasized how these views also differ in significant ways [...] After first reviewing certain core ideas of the enactive approach [...] we focus on [...] the difference between 'incorporation' and mere 'extension' in the body-mind environment relation (THOMPSON 2009, p. 23).
} 
mundo [world-mirroring] segundo correlações com uma base física de realização (ENGEL 2010, p. 222-3). As teorias 4E's atenuam a determinação internalista de existência de cérebro, sistema nervoso ou sistema material equivalente como condição da compreensão da cognição. Desse modo, as teorias 4'Es conjugam não-internalismo e não-representacionalismo que, nos termos de James e Whitehead, significam nãointelectualismo. As teorias 4E's ganharam também novos contornos filosóficos e impulsionaram uma tendência filosófica que rivaliza com o funcionalistmo tradicional em termos de teorias computacionais e representacionais da mente (NOË 2006; HUTO; MYIN, 2013).

Retomando o empirismo de James e Whitehead, ele supõe duas premissas que mostram sintonia com as teorias 4E's: de um lado, a premissa da continuidade: entidades cognitivas estão situadas no mundo e, com efeito, a relação com o mundo forma um continuum (MALACHOWSKI 2013, p. 40); de outro, a premissa do pluralismo: o mundo nunca se apresenta como fato único e absoluto a um ponto de vista particular (JAMES [1897] 1977, p. 135). ${ }^{27}$ Seguindo as premissas de continuidade e pluralismo, creio ser razoável uma revisão da lacuna explicativa como designando uma visão internalista de mente como uma entidade enclausurada no

\footnotetext{
${ }^{27}$ Ao apresentar o pragmatismo como uma forma de humanismo, James mostra uma perspectiva muito próxima a Thomas Nagel (1986) no sentido de que a experiência não tem um último ponto de vista - o que Nagel designa 'visão de lugar nenhum'. E contrariamente à concepção moderna de experiência como movimento centrípeto em relação ao mundo, para James, a experiência tem a estrutura de uma rede endógena e ao mesmo tempo centrífuga. A noção de 'rede' [web] descreve o caráter inter-relacional da experiência como processo dinâmico: '[...] owing to the fact that all experience is process, no point of view can ever be the last one [...] if you then forget that this standard perceptually grows up endogenously inside the web of the experience, you may careless go on to say that what distributively holds of each experience, holds also collectively of all experience, and that experience as such and in its totally owes whatever truth it may be possessed-of its correspondence with absolute realities outside of its own being (JAMES [1094] 1978, p. 221). O que se observa também é que a noção de rede [web] descreve a forma holista da experiência que tem consequente implicação epistemológica (JAMES [1905] 1977, p. 191). Neste sentido, por exemplo, a noção de 'rede' evoca a descrição do conhecimento de Quine e Ullian (1978) como 'rede de crenças'.

Cont.
} 
cérebro $^{28}$. Em contextos mais atuais em filosofia da mente e ciências cognitivas, o internalismo cede lugar à noção de 'mente estendida' [extended mind]. Assim é a tese de Chalmers e Clark (2002) sobre 'externalismo ativo'. Diferentemente do externalismo tradicional, essa forma de externalismo procura destacar a continuidade com o meio e o papel que ele tem em conduzir os processos cognitivos (CLARK 2011, p. 222-3). Seguindo a tese de Chalmers e Clark, Menary (2010) avança a noção de 'mente estendida' e rompe com o pressuposto epistemológico de descontinuidade mente e mundo.

Como ilustração dessa tendência não-internalista, se destaca aqui um artigo de John Pickering (2005, p. 2-3) sobre cognição incorporada e a concepção de processo de Whitehead. Nesse artigo, Pickering explora uma abordagem de cognição e mente alternativamente ao internalismo. Também nesse contexto, um instigante artigo de Joel Krueger (2006) articula as noções de experiência de James e mente estendida em defesa de uma concepção externalista de mente. Conforme tais perspectivas, não se pode determinar precisamente onde termina a mente e começa o mundo (CLARK 2011, p. 220; 226). ${ }^{29}$ É preciso estar claro que extensão não significa uma ontologia substancialista em que se compreende a realidade como uma sucessão de níveis de organização

\footnotetext{
${ }^{28}$ Seguindo a ideia de 'ajuste' entre organismo e meio, ao propor uma abordagem enativa em filosofia da mente, Alva Noë rejeita o internalismo tradicional segundo a qual a percepção está confinada ao interior do indivíduo e assinada o caráter ativo de percepção: 'Perceivers aren't confined to their retinal images in the way traditional theorists have supposed [...] just as there is a fit between an animal and the environment ... so there is a tight perceptual attenument animal and environment. Because of this attunement, animals (as embodied wholes, not as brain system attached to photoreceptors) are directly sensitive to the features of the world that afford the animal opportunities for action (NOË 2006, p. 20-1).

${ }^{29}$ A propósito, vale destacar, segundo Whitehead: 'There is no definite boundary to determine where the body begins and the external nature ends' (WHITEHEAD 1938, p. 221). Muitos filósofos e cientistas tomam a dissolução de limite entre interno e externo como afirmação de uma concepção de mente e cognição estendidas.

Cont.
} 
(partículas elementares, átomos, moléculas, células, organismos, e assim por diante).$^{30}$ Tendo em vista o panexperiementalismo de James e Whitehead, como forma de um construtivismo radical, a realidade é uma hierarquia de processos que se estabilizam em diferentes escalas temporais (cf. NICHOLSON and DUPRÉ 2018, p. 21). Para Whitehead, organismo não representa um nível de organização com uma fronteira definida e um repertório fixo de propriedades. Um organismo é essencialmente processo sem fronteira rigidamente definida com o meio e com períodos de estabilidade temporal.

Segundo as perspectivas de mente estendida, 'mente' não representa uma entidade enclausurada no cérebro e pode ser melhor compreendida como processo, forma e grau de organização funcional entre diferentes tipos de entidades biológicas $^{31}$. Nos termos do panexperiementalismo de James e Whitehead, comparativamente, assim como as noções de experiência e organismo, mente também significa processo.

\footnotetext{
${ }^{30}$ Entendendo-se mente e cognição como processos, formas e graus de organização funcional de entidades biológicas, pode-se aqui traçar um paralelo histórico com a crítica à noção mecanicista de organismo como máquina. Em The Interpretation of Development and Heredity, por exemplo, Edward Stuart Russell afirma: '[t]he organism is not, like a machine, a static construction, but a constantly changing organization of functional activities' (RUSSELL 1930, p. 169).

31 '[...] there are aspects of cell life that suggest the presence of forerunners of a "feeling" function. Unicellular organisms are "sensitive" to threatening intrusions [...] But what about the other side of this behavior, namely, the cell's internal state? The cell does not have a brain, let alone a mind to "feel" the pokes, and yet it responds because something changed in its interior. Transpose the situation to neurons, and therein could reside the physical state whose modulation and amplification, via larger and larger circuits of cells, could yield a protofeeling, the honorable counterpart of the protocognition that arises at the same level' (DAMASIO 2010, p. 196).

'Dalai Lama: Therefore, would you consider a one-celled creature like an amoeba a sentient being?

Varela: Yes. From this point of view, there is no question. There is no way for me to draw a line and distinguish my cognition from the cognition of frogs, hydras, amoebas, or bacteria' (HAYWARD; VARELA 2001, p. 67)
} 


\section{HOLISMO, CONTINUIDADE E QUALIA}

Embora como parte final, esta talvez seja núcleo do artigo. Aqui pretendo mostrar como o empirismo de James e Whitehead desenvolve aspectos holistas em epistemologia e filosofia da mente. De um lado, em epistemologia, James e Whitehead afirmam uma concepção anti-fundacionalista de conhecimento em termos de uma rede de relações; de outro, em filosofia da mente, eles negam uma visão internalista de mente em termos de correlações estritas com o cérebro. Em paralelo com o enativismo de Evan Thompson (2004; 2007), segundo o qual a organização e as características mentais distintivas (entre elas, qualia) representam versões de estruturas e princípio da própria vida biológica, para James e Whitehead, a compreensão de mente e a justificação do conhecimento têm como pressupostos holismo e continuidade.

Segundo James ([1904] 1977, p. 172), a experiência não tem duplicação interna e muito menos sustenta uma descontinuidade entre mente e mundo. É interessante notar aqui o significado polivalente da experiência. De um ponto de vista interno ou subjetivo, experiência significa o 'fluxo imediato da vida' sob o qual se estabelecem as categorias conceituais e é o nome do estado de sentimento e sensação indiferenciados (JAMES [1905] 1977, p. 215). De um ponto de vista externo ou objetivo, experiência é a matéria primitiva do mundo da qual tudo se compõe (JAMES [1904] 1977, p. 170) - tudo que é experenciado é real e parte da experiência. Como terceiro aspecto, a experiência é a relação em uníssono entre subjetivo e objetivo: cada parte do mundo é um experenciar ou um experenciado e, portanto, nada existe que não seja experiência. Na medida em que a realidade é experiência, perde sentido a descontinuidade cartesiana entre uma substância experenciante (e inextensa) e uma substância 
experienciada (e extensa no mundo) - é no fluxo da experiência que é dada a união das coisas (JAMES 1909, p. 281). Negando a duplicidade interna da experiência, James mostra como um mesmo item pode estar em dois grupos ao mesmo tempo: na loja de tintas, em um grupo, a 'tinta' pode figurar como 'pensamento' e, em outro, como 'coisa' (JAMES [1904] 1977, p. 172) - a 'tinta' é numericamente o mesmo item tomado em duas porções diferentes da experiência. Segundo James ([1904] 1977, p. 173), o enigma de como um mesmo item pode estar em dois lugares é como um ponto que está na interseção de duas retas. $O$ ponto de interseção ilustra bem como a experiência é uma relação em uníssono que sustenta a continuidade mente e mundo.

Uma das críticas de Whitehead à metafísica tradicional é a noção de 'substância' que implica 'localização simples' [simple location]: a substância é o substrato do qual se predica uma qualidade segundo a localização simples de uma entidade no espaço e tempo. Já em Science and The Modern World ([1925] 1948, p. 54), e anterior a Process and Reality ([1929] 1978), Whitehead questiona a estrutura explicativa da noção de localização simples segundo princípios da física contemporânea (EISENDRATH 1971, p. 21-2). A rejeição da noção de localização simples significa também a rejeição da noção de matéria e, com efeito, Whitehead mobiliza a estrutura explicativa das teorias de campos na física contemporânea. ${ }^{32}$ Para ele, uma 'entidade' não significa uma porção de

\footnotetext{
32 '[...] can we define an organism without recurrence to the concept of matter in simple location? [...] The same relegation of matter to the background occurs in connection with the electromagnetic fields. The modern theory presupposes happenings in that field which are divorced from immediate dependence upon matter' (WHITEHEAD [1925] 1948, p. 104). Em seu influente Living Systems, destaca James G. Miller, eminente biólogo sistêmico e whitheadiano declarado, que a metáfora do campo está presente em muitas diferentes teorias: The twentieth century characteristically has drawn its metaphors from Einstein's relativistic field theory, which clearly influences the philosophy of organism of Whitehead, the Gestalt psychology of Wertheimer, Kohler, and Koffka, and general systems theory [...] in spite of their differences, all recognize that the interrelationships among Cont.
} 
matéria em localização simples no mundo. Como notara Russell (1954), nosso conhecimento das entidades externas é estrutural e não se determina em termos das noções de massa e substância. Se assim considerada, a noção de entidade revela uma abstração ou o que Whitehead ([1925] 1948, p. 104) designa 'falácia da concretude deslocada' [fallacy of misplaced concreteness]. E se considerada uma visão materialista de mundo, a falácia consiste em se procurar uma explicação de mente em termos de uma porção interna de matéria e localização no cérebro.

James também mobiliza a noção de 'campo' como um componente da experiência e continuidade mente e mundo. ${ }^{33}$ Incorporada a uma estrutura de compreensão da realidade, a noção de campo representa uma metáfora espacial (LAMBERTH 1999, p. 90). Ela proporciona a James inserir mente e mundo como partes seccionais do fluxo da experiência. $\mathrm{O}$ conhecimento do mental, portanto, não se estabeleceria em termos de explicação material do mundo ou de correlações estritas com o cérebro. $\mathrm{O}$ que se pode conhecer do mental concretamente são relações com o mundo, que incluem o cérebro, concatenadas ao fluxo contínuo da experiência.

Como já destacado acima, uma noção fundamental da epistemologia de Whitehead ([1925] 1948, p. 70; [1929] 1978, p. 18-9) é 'preensão'. Ao contrário de apreensão mental, preensão é parte do esquema categorial de explicação da realidade. Uma entidade percebida é um objeto dos sentidos como, por exemplo, o verde de um objeto. Mas, argumenta

coacting components of an organized whole are of fundamental importance in understanding the totality (MILLER 1978, p. xiv).

33 'Our fields of experience have no more definite boundaries than have our fields of view. Both are fringed forever by a more that continuously develops, and that continuously supersedes them as life proceeds. The relations, generally speaking, are as real here as the terms are' (JAMES [1909] 1977, p. 207). 
Whitehead ([1925] 1948, p. 72), o verde não está simplesmente localizado na mente perceptiva e muito menos está situado no objeto percebido: o verde está presente na mente perceptiva com modo de localização no objeto. Seguindo os princípios de processo e continuidade, para Whitehead ([1925] 1948, p. 73), 'o mundo real é um desdobramento de várias preensões'. Como James, a epistemologia de Whitehead indica uma perspectiva relacional e holista que dispensa as noções de localização simples e relação substânciaqualidade $^{34}$. Para Whitehead, igualmente fundamental e associada à noção de preensão, é o significado de 'concrescência' [concrescence]. De sua raiz latina, 'concrescência' significa o crescer junto de muitas coisas em uma nova unidade. ${ }^{35}$ Concrescência acrescenta à noção de preensão o caráter holista de conhecimento e visão de mundo de Whitehead.

Considerando o exemplo de Whitehead sobre a preensão do verde, pode-se contextualizar aqui o problema dos qualia. E nada ilustra melhor a lacuna explicativa do que a compreensão do significado dos qualia. Segundo Tim Crane (2000), a origem dos qualia é uma invenção da filosofia americana entre final do Século XIX e início do Século XX. James emprega o termo quale em referência às características distintivas das sensações ${ }^{36}$. Clarence Lewis, ex-aluno de James em

\footnotetext{
${ }^{34}$ Investigators concerned with an analysis of the logical structure of natural sciences have insisted that the transition from concepts of 'substance' to concepts of 'function' is characteristic of the historical development of science. 'Thing-concepts' have gradually and often painfully yielded to 'relational concepts' [...] In this connexion Dr Hayek's theory appears very modern indeed since not even traces of 'thing-concepts' are left in his theory. 'Mind' for him has turned into a complex of relations; it is simply 'a particular order of a set of events taking place in some organism and in some manner related to, but not identical with, the physical order of events in the environment' (KLÜVER 1952, p. xx).

35 "'Concrescence' is the name for the process in which the universe of many things acquires an individual unity in a determinate relegation of each item of the 'many' to its subordination in the constitution of the novel tone"” (WHITEHEAD [1929] 1978, p. 211).

${ }^{36}$ No Capitulo The Perception of Space, Principles of Psychology, ([1890] 1952, p. 553), William James assinala: No single quale of sensation can, by itself, amount to a consciousness of position [...] a feeling of place cannot possibly form an immanent element in any single isolated sensation. Cont.
} 
Harvard, quando publica Mind and the World Order em 1929, parece expressar vivamente a influência do antigo professor. Para Lewis, um problema de difícil contorno é que se confunde e se usam indistintamente os mesmos predicados para qualia e para propriedades de objetos. Não há nome na linguagem comum para qualia e, com efeito, eles são indicados por 'parecer' [looks like]. Quando se compara qualia ('vermelhidade', 'sonoridade' etc.) com certas propriedades no mundo, estabelecemos relações e paralelos: os qualia 'vermelhidade' ou 'sonoridade' da experiência, por exemplo, têm relações e paralelos com eventos no mundo (objetos são vermelhos, sonoros etc.). Embora qualia não seja o termo usado por James em The Function of Cognition ([1909] 1977, p. 1389/141) - de fato, ele usa 'feeling' -, Lewis retoma o problema do antigo professor sobre a função cognitiva dos qualia: como uma realidade se assemelha a um quale?

O influente artigo de Thomas Nagel What is it like to be a bat? (1974) ilustra bem a dificuldade de acomodação dos qualia segundo a estrutura materialista de explicação do mental. Para Nagel, é a consciência que torna o problema mente-cérebro intratável e ele ataca as tentativas de redução psicofísica. Na experiência de um organismo, há alguma coisa que significa o que é ser para aquele organismo: é o caráter subjetivo e a perspectiva da experiência que não podem ser analisados por nenhuma descrição psicofísica ou funcional da dos estados internos do organismo. Ainda segundo Nagel, o caráter subjetivo está conectado a um ponto de vista particular da experiência. Como consequência, uma assimetria se impõe entre certo conteúdo epistêmico da experiência e uma

\footnotetext{
Também em seu empirismo radical, assinala James ([1904] 1977, p. 282): 'the word 'activity' has no imaginable content whatever save these experiences of process, obstruction, striving, strain, or release, ultimate qualia as they are of the life given us to be known'. No sentido contemporâneo do termo, Charles S. Peirce (CP 6.222) também emprega o termo 'quale': [it is] 'that is the way things look to'.
} 
eventual redução psicofísica. Considerando tal assimetria, qualia significariam conteúdos únicos e irredutíveis da experiência. Em sentido crítico e oposto a Nagel, uma referência de Daniel Dennett merece destaque aqui: Quining qualia (1988). Ao usar o verbo 'quinear', Dennett nega que qualia tenham existência e significado real: 'quine, v. To deny resolutely the existence or importance of something real or significant' (DENNETT 1988, p. 381). Como consequência, ele propõe a dissolução dos qualia segundo um procedimento de quineamento [quinging] dos termos mentais. E àqueles que insistem sobre o significado real dos qualia, Dennett (1993, p. 212) confere a eles a denominação de 'qualophiles'. Como resultado, Dennett desenvolve uma qualiaphobia. Não me parece que a qualiaphobia de Dennett tenha sido uma alternativa promissora de tratar o problema dos qualia.

Como assinala Clarence Lewis, as palavras significam diferentes objetos em diferentes contextos relacionais. Por exemplo, a palavra 'verde' pode significar a propriedade ou realidade externa de uma coisa física e igualmente pode significar uma alguma coisa mental. De modo comparativo, o uso da palavra 'dor' não tem um significado uniforme e ele varia em função do contexto ao qual ela é levada. Os diferentes contextos não justificam a afirmação de uma descontinuidade epistemológica ou lacuna explicativa em torno dos usos das palavras 'verde' ou 'dor'. Se o uso da palavra 'dor' significa o aspecto mental de uma experiência, certamente, tal uso não veicula um tipo especial de conhecimento em descontinuidade com o mundo. Como destaca James em The function of cognition ([1884] 1977), não somente o significado prático do uso das palavras, mas igualmente relevante, é compreender o que o contexto representa em termos de distinção do 
significado dos conteúdos da experiência. ${ }^{37}$ De modo análogo, para Whitehead, o conteúdo sensorial 'verde' está presente na mente perceptiva em continuidade com modo de localização no objeto percebido como verde. Ao contrário de uma visão internalista, a forma de empirismo de James e Whitehead nos permite situar os qualia segundo relações de continuidade e pluralidade em contextos da experiência ${ }^{38}$. Como no exemplo da tinta, acima descrito, um item que se apresenta em duas porções da experiência revela um vetor topológico. Whitehead ([1929] 1978, p. 19; 55; 116), por exemplo, assim como a atividade preensitiva, descreve também o 'caráter de vetor' da experiência.

Para René Thom ([1972] 1975), o grande nome da topologia recente, em um espaço topológico, um objeto é um subconjunto fechado e o que se designa comumente 'coisas' representam 'formas' ou 'estruturas' com certo grau de estabilidade: elas ocupam parte do espaço e duram um período de tempo. Segundo Thom (1969, p. 313), a topologia fornece uma ferramenta que permite reconstruir uma forma global através das propriedades locais ${ }^{39}$. Assim me parece ser a descrição dos qualia: como se reconstruir a forma de uma experiência que tem duração quase instantânea. A ideia de

\footnotetext{
37 'There is practically no test for deciding whether the feeling of a bare quality means to represent it or not [...] Being without context or environment or principium individuationis, a quiddity with no haecceity, a platonic idea, even duplicate editions of a such a quality (were they possible), would be indiscernible, and no sign could be given' (JAMES [1884] 1977, p. 143).

${ }^{38}$ No artigo The Mind-Body Problem and Whitehead's Non-reductive Monism (2012), coincidentemente, Anderson Weekes argumenta que o tratamento dos qualia por Whitehead evita o 'problema difícil' [hard problem] se considerado como resultado da lacuna explicativa. Embora não seja uma terminologia usada por Weeks, o argumento desenvolvido por ele mostra que as entidades reais [actual entities] têm uma natureza externamente relacional e internamente dipolar (física e mental). $\mathrm{O}$ argumento reafirma a ideia de continuidade epistemológica na compreensão de físico e mental que, em particular, tende a dissipar a lacuna explicativa.

${ }^{39}$ Como Whithead, e não por acaso, o esquema ontológico da topologia de René Thom tem como referência o processualismo de Herálcito: 'Our dynamical schemes remind us of the old Heraclitean ideas [and] provide us with a very powerful tool to reconstruct the dynamical origin of any morphological process [and] understanding of the structure of many phenomena of animate and inanimate nature' (THOM 1969, p. 313; 334).

Cont.
} 
reconstrução topológica fortalece filosoficamente o caráter holística da experiência contra a visão internalista de mente derivada da lacuna explicativa ${ }^{40}$.

Em consonância com a noção de espaço topológico, em termos de processo, Whitehead ([1929] 1978, p. xiii) enfatiza que 'a relação é dominante sobre a qualidade'. Para ele, não se descreve a realidade em termos da 'morfologia de coisas' (WHITEHEAD [1929] 1978, p. 41). Como a noção de forma de René Thom que tem certa estabilidade espaço-temporal, Whitehead ([1929] 1978, p. 29) insiste que a forma é permanente (e não a substância) e é ela que está sujeita à mudança de relações. Assim, por exemplo, a descrição topológica do processo de preensão do 'verde' (como vetor especial) descredencia a imagem atomista dos qualia como conteúdos discretos da experiência em descontinuidade com o mundo. Como vetor espacial, a noção de preensão destaca o fato de que a experiência total implica, no mínimo, dois termos e, portanto, não está sujeita à descrição em termos da noção de localização simples (EMMET 1932, p. 93). A noção de preensão também destaca os seguintes pontos: 1) não se pode descrever uma experiência em termos de processo linear causal; e 2) uma experiência mostra não ter morfologicamente a estrutura de substância que sustenta certas qualidades. Como destaca James, não se apreende um quale isoladamente. Assim, como forma, qualia têm uma estrutura

\footnotetext{
${ }^{40} \mathrm{Na}$ apresentação de The Sensory Order de F. A. Hayek (1952), um extenso ensaio em psicologia, Heinrich Klüver destaca vários aspectos que indicam uma abordagem processualista da mente e, em particular, a ideia de descrição topológica dos eventos mentais como uma estrutura complexa de conexões: 'A wide range of mental phenomena, such as discrimination, equivalence of stimuli, generalization, transfer, abstraction, and conceptual thought, may all be interpreted as different forms of the same process of classification which is operative in creating the sensory order. The fact that this classification is determined by the position (in a topological, not a spatial, sense) of the individual impulse or group of impulses in a complex structure of connexions, extending through a hierarchy of levels, has important consequences when it comes to considering the effects of physiological or anatomical changes' (KLÜVER 1952, p. xix-xx).
}

Cont. 
topológica não-linear como parte do continnum da experiência $^{41}$. Tal estrutura relacional tem a forma temporal do que James chama 'presente especial': a experiência do presente não corresponde a um ponto com quase zero de duração que pode ser matemática ou fisicamente representado em uma escala separando passado e presente. Para James ([1890] 1983, p. 574), ao contrário de um único instante de tempo, a experiência concreta do presente tem uma forma expandida e não-linear.

Como consequência dessa compreensão do caráter contínuo e não-linear da experiência, pode-se traduzir os qualia como formas e não como qualidades sensoriais discretas. A ideia de forma desabilita a imagem internalista de mente que a lacuna explicativa inspira. Conforme a estrutura topológica da experiência nos termos de James e Whitehead, qualia representam formas em que experiência conjuga com as formas do mundo. Se se argumentar que tal descrição dos qualia equivale a afirmar que 'dor é ativação das fibras-C' e que, portanto, alguma coisa da experiência ainda está inexplicada, só tenho a dizer que procurar a natureza dos qualia em uma 'lacuna' epistemológica é procurar o fantasma na máquina e parte da narrativa de uma mitologia filosófica. $\mathrm{O}$ que estou desenvolvendo é uma abordagem naturalista de qualia que, contudo, não assume pressupostos ontológicos e epistemológicos do internalismo em filosofia da mente. De um ponto de vista internalista, embora certas identidades psicofísicas incluam ontologicamente os qualia, eles não estariam incluídos na rede causal de eventos no mundo e seriam declarados epifenômenos. Aqui, alternativamente, procuro evidenciar o

\footnotetext{
${ }^{41}$ Citando Riemann, em Esquisse d'une Sémiophysique, René Thom (1988, p. 213) observa que um modelo topológico descreve a significação do pensamento como a 'forma de processos neurofisiológicos subjacentes' que tem consequência a 'realização do programa monista de interação mente e cérebro'.

Cont.
} 
caráter fenomênico dos qualia e como eles estão incluídos na rede causal de relação mente e mundo ${ }^{42}$.

É importante destacar que a noção de espaço topológico robustece as premissas de continuidade e holismo do empirismo de James e Whitehead. Em oposição a uma visão internalista de mente, o empirismo de James e Whitehead indica que qualia não teriam significado senão conforme a perspectiva de continuidade e holismo da experiência. De novo, quero insistir que se trata do significado dos qualia como formas da experiência concatenada às formas do mundo. Como estrutura topológica, 'forma' é essencialmente uma entidade relacional. Assim como entendo, a suposta natureza inexplicada dos qualia é personagem de uma mitologia e filosoficamente um non-sense. Como formas, qualia podem ser compreendidos como elementos de um continuum espaço-temporal da experiência.

Tendo em vista tal significado dos qualia, pode-se destacar uma forma latente de adverbialismo no empirismo de James e Whitehead. Em filosofia da mente, o adverbialismo recusa o compromisso com a forma diádica experiência-propriedade. Como caso paradigmático, temos a experiência de dor: ela é uma forma da própria experiência e não significa uma relação entre dois lugares (experiência e propriedade). Da parte de James e Whitehead, o adverbialismo significa que a experiência não tem duplicidade interna entre conteúdos fenomenal (experenciar) e representacional (experenciado) - ambos são partes do continuum da experiência; logo, perde sentido a descrição da experiência segundo o modelo diádico substância-qualidade (EISENDRATH 1971, p. 41).

\footnotetext{
${ }^{42}$ Em The Cambridge Handbook of Situated Cognition (2009), coincidentemente, Philip Robbins e Murat Aydede destacam a natureza transacional da qualidade da experiência visual. A ideia é que não se trata de um conteúdo enclausurado da experiência e tem muito mais a ver com processos dinâmicos: 'the enactivist idea that the felt quality of visual awareness is a by-product of ongoing agent-environment interaction' (Robbins e Aydede, 2009, p. 7).
} 
Assim considerando o adverbialismo de James e Whitehead, qualia significam formas da experiência em continuidade com o mundo - o verde do experienciar tem também modo de localização no mundo experenciado. Como Whitehead recusa a noção de localização simples, James ([1890] 1952, p. 553) afirma que não se tem de um quale a experiência de uma entidade atômica (HUTTO; MYN 2013, p. 156).

Aqui, em particular, se destaca o Capítulo Theories of Bifurcation of Nature de The Concept of Nature em que Whitehead desenvolve uma crítica à noção de bifurcação ${ }^{43}$. Para ele, tem sido (e em grande parte ainda é) uma tendência contemporânea entre filosofia e ciência considerar a natureza em duas realidades separadas: enquanto a mente corresponde à realidade interna, o mundo corresponde à realidade externa da natureza. Da noção de bifurcação na natureza, pactuam dualismo e materialismo. Para Whitehead, alternativamente, o que está na experiência está em interação com a natureza. Por exemplo, é o caso da percepção das qualidades secundárias (WHITEHEAD 1920, p. 27). As qualidades secundárias não são simples epifenômenos sem existência. Como assinalado na Introdução deste artigo, tal é a visão de uma longa tradição desde Demócrito a Galileu, Schroedinger e materialistas contemporâneos em filosofia da mente. Do ponto de vista de Whitehead, qualidades secundárias representam a realidade fenomenal da natureza - aqui também se incluiriam os qualia ${ }^{44}$. Para Whitehead, perceber as qualidades

\footnotetext{
43 'What I am essentially protesting against is the bifurcation of nature into two systems of reality [...] One reality would be the entities such as electrons which are the study of speculative physics. This would be the reality which is there for knowledge [...] For what is known is the other sort of reality, which is the byplay of the mind' (WHITEHEAD 1920, p. 30).

44 'This is exactly what scientific philosophers do [...] They at once drag in the mind and talk of entities in the mind or out of the mind as the case may be. For natural philosophy, everything perceived is in nature. We may not pick and choose. For us, the red glow of the sunset should be as much part of nature as are the molecules and electric waves by which men of science would explain the phenomenon. It is for natural philosophy to analyze how these various elements of nature are connected' (WHITEHEAD 1920, p. 29)
} 
secundárias consiste em um processo que pertence ao aspecto fenomenal da própria natureza.

Como consequência das teorias da bifurcação, tornou-se inevitável uma visão epifenomenalista do mental. Uma versão fisicalista do epifenomenalismo afirma que o 'mental qua mental' não tem eficácia causal (DAVIDSON 1972). James ([1890] 1952, p. 89) teria sido o primeiro a usar o termo 'epifenômeno' em Principle of Psychology. Anteriormente, em Are we automata? (1879), ele qualificara o epifenomenalismo como The Automaton-Theory ou Conscious-Automaton Theory. Contra tal teoria, James (1879, p. 10; [1890] 1952, p. 94) designa uma 'Theory of Common Sense'. A 'linguagem do senso comum' eliminaria a lacuna [chasm] entre consciência e mundo: usando a linguagem do senso comum, segundo James, ninguém pode negar que os estados mentais tenham eficácia causal e continuidade com o mundo quando eles significam ou intencionam um objeto - a mente não só recebe, mas ela também seleciona sensações (JAMES [1890] 1952, p. 185). Como James, Whitehead também reconhece a eficácia causal das ideais e, portanto, recusa o aspecto epifenomenal do mental (EISENDRATH 1971, p. 230). Embora o título do artigo de James seja uma clara referência ao mecanicismo de Descartes, ele pode ser muito bem atualizado como crítica ao epifenomenalismo fisicalista e consoante com a negação das teorias da bifurcação por Whitehead.

Também como ilustração de dissolução da lacuna explicativa, retomo uma estória contada por James ([1907] 2000, p. 24): de um lado do tronco de uma árvore, agarrado a ele, está um esquilo; do lado oposto ao esquilo, está uma pessoa. Não importa quão rápido a pessoa tenta alcançar o esquilo, ele se move ainda mais rápido e a árvore está sempre entre eles. Dois grupos animam uma calorosa discussão: enquanto um grupo afirma que a pessoa contornou o esquilo, o grupo 
rival afirma que a pessoa não contornou o esquilo. Os grupos pedem a James uma opinião que pudesse resolver a querela. E ele responde: 'Which party is right ... depends on what you practically mean by 'going round' the squirrel' (JAMES [1907] 2000, p. 24). Como exemplo de aplicação do método pragmático, James afirma que ambos os lados da disputa podem estar certos e errados de acordo com o que o verbo 'contornar' significa. Para ele (JAMES [1907] 1977, p. 377), tornando clara a distinção prática de significação das palavras, não teremos ocasião de novas disputas.

Se, comparativamente à estória do esquilo e o significado de 'contornar', o termo psicológico 'dor' significa 'ativação das Fibras-C' e, como hipótese rival, a afirmação é negada, e 'dor' não significa 'ativação das Fibras-C', os usos do termo 'dor' significariam uma lacuna explicativa entre dois tipos de conhecimento? Pouco provável! Embora a lacuna explicativa suponha uma premissa epistemológica, ela parece muito melhor situada como problema metafísico e objeto de disputa verbal. Se tornados claros os usos do termo 'dor', não teremos razão em admitir descontinuidade epistemológica ou lacuna explicativa na afirmação 'dor é ativação das fibras-C'.

A matriz mitológica da lacuna explicativa consiste em promover uma descontinuidade epistemológica enquanto se afirma a continuidade ontológica. Quando James e Whitehead mobilizam as respectivas noções de experiência e processo, seguindo a noção de campo, eles mostram que o conhecimento do mental não se estabelece senão em termos de continuidade com o mundo (e que também incluiria o cérebro): temos experiência do mundo e o cérebro é parte da nossa experiência. Tal concepção evidencia o significado epistemológico da premissa de continuidade no empirismo de James e Whitehead. Assim, a fórmula de dissolução da lacuna explicativa pode ser resumida em termos de 
continuidade das respectivas noções de James e Whitehead de experiência e processo que sugerem o caráter de externalidade e eventualidade do mental.

\section{CONSIDERAÇÕES FINAIS}

Tratar a lacuna explicativa como mito não significa absolutamente um demérito à relevância que ela teve em vários e importantes debates em filosofia da mente. Assim como a estrutura dos mitos tem um limiar de alcance explicativo, também a lacuna explicativa alcançou um limiar; e não somente um limiar epistemológico. A visão de mente que ela inspira também parece exaurida.

Tendo em vista as respectivas noções de experiência e processo de James e Whitehead, o artigo procura mostrar que o problema da lacuna explicativa é um mito filosófico na medida em que se sustenta uma continuidade ontológica e ao mesmo tempo uma descontinuidade epistemológica entre mente e mundo ou mente e cérebro. Dada tal incongruência entre continuidade ontológica e descontinuidade epistemológica, a narrativa da lacuna explicativa se converte em procura pelo fantasma na máquina e, como consequência, assume a forma de mito filosófico.

$\mathrm{O}$ artigo apresenta finalmente o empirismo de James e Whitehead que, partindo da premissa de continuidade, indica uma alternativa ao déficit epistemológico da lacuna explicativa assim como à visão de mente que ela inspira. $\mathrm{O}$ resultado mostra a atualidade do empirismo de James e Whitehead consoante com as crescentes abordagens não-internalistas de mente e cognição segundo a ideia de graus de organização funcional de diferentes tipos de experiência e processo.

Abstract: the paper presents a re-reading of the explanatory gap problem 
starting from the empiricism of William James and Alfred N. Whitehead. Given the respective notions of experience and process of James and Whitehead, the paper seeks to show that the explanatory gap is a philosophical myth in the sense that an ontological continuity is maintained and at the same time combined with an epistemological discontinuity between mind and world or mind and brain - in particular, as illustration of such an incongruity between continuity and discontinuity, the core of the paper is centered around the review of the so-called qualia problem. From the empiricism of James and Whitehead, and in view of the notion of continuity, the paper indicates an alternative to the epistemological deficit of the explanatory gap as well as to the internalist view of mind that it inspires - the idea that the mind is cloistered in the brain. As result, the paper points the timeliness of James and Whitehead's empiricism in line with the growing non-internalist approaches of mind and cognition in terms of continuity suggested by the respective notions of James and Whitehead's experience and process.

Keywords: James; Whitehead; Explanatory Gap; Myth.

\section{REFERÊNCIAS}

ARAUJO, Arthur. William James and Jakob von Uexküll: pragmatism, pluralism and the outline of a philosophy of organism. Cognitio-Estudos, V. 11, n. 2, 2014.

. William James and Jakob von Uexküll: pragmatism, pluralism and the outline of a philosophy of organism. In: Orpheus' Glance. Selected papers on process psychology. Edited by Michel Weber and Paul Stenner. Louvain-laNeuve: Les Éditions Chromatika, 2018.

The explanatory gap: the pragmatic deconstruction of a myth. Cognitio, V. 19, n. 1, 2018.

-William James, Jakob von Uexküll et la critique des notions de représentation mentale et d'intentionnalité. Philosophical Enquiries - Revue de Philosophies Anglophone, V. 1, 2016. 
BARTHES, Roland. Mitologias. Trad. Rita Buongermino e Pedro de Souza. São Paulo: Difel, 1982.

CARNAP, Rudolf. Psychology in Physical Language. Erkenntnis. Berlim, n.3, pp. 39-44, 1932.

CHALMERS, David. The Conscious Mind. Oxford: Oxford University Press, 1996.

Panpsychism and Panprotopsychism. In: Panpsychism - Contemporary Perspectives. Edited by Godehard Brüntrup and Ludwig Jaskolla. Oxford: Oxford University Press, 2017.

CHALMERS, David; CLARK, Andrew. The Extended Mind. In: CHALMERS, David (ed.). Philosophy of Mind: Classical and Contemporary Readings. Oxford: Oxford University Press, 2002, p. 643-651.

CLARK, Andy. Supersizing the mind-embodiment, action and cognitive extension. Oxford: Oxford University Press, 2011.

CRANE, Tim. The History of the Mind-Body Problem. London: Routledge, 2000.

DAMASIO, Antonio. Self comes to mind - constructing the conscious brain. New York: Pantheon Books, 2010.

DAVIDSON, Donald. Essays on Actions \& Events. Oxford: Oxford University Press, 1980.

DEACON, Terrence. Incomplete Nature - how mind emerged from matter. New York: W. W. Norton \& Company, 2012. 
DENNETT, Daniel. Consciousness Explained. London: Peguin Books, 1993.

. Quining Qualia. In: MARCEL, A; BISIACH, E. (eds.) Consciousness in Modern Science. Oxford: Oxford University Press, 1988, p. 42-77.

EISENDRATH, Craig. The Unifying Moment - The Psychological Philosophy of William James and Alfred N. Whitehead. Cambridge: Harvard University Press, 1971.

EMMET, Dorothy M. Whitehead's Philosphy of Organism. London: MacMillian and Co., 1932.

ENGEL, Andreas K. Direct Minds: How Dynamics Shapes Cogniton. In: STEWART, John. Enaction - Toward a New Paradigm for Cognitive Science. Cambridge: The MIT Books, 2010, p. 219-243.

HAYEK, Friedrich A. The Sensory Order. Chicago: The University of Chicago Press, 1952.

HAYWARD, J. W., VARELA. F. J. Gentle Bridges. Conversations with the Dalai Lama on Sciences of Mind. Shambala Publications Inc. (2001)

FLANAGAN, Owen. Consciousness as a pragmatist views it. In: PUTNAM, Ruth Anna (ed.). The Cambridge Companion to William James. Cambridge: Cambridge University Press, 1997.

HUTTO, Daniel; MYN, Erik. Radicalizing Enactivism. Cambridge: MIT Press, 2013.

JACKSON, Frank. What Mary didn't know. Journal of Philosophy. n. 83, p. 291-295, 1986. 
JAMES, William. Are we automata? Mind. 4, p. 1-22, 1879. Pluralistic Universe. New York: Longmans, Green, And Co., 1909.

. Pragmatism and The Meaning of Truth. Cambridge (MA): Harvard Univesity Press, 1978.

. The Principles of Psychology. Cambridge (MA): Harvard Univesity Press, 1981.

. The Principles of Psychology. Chicago: The Great Books/Chicago Univesity, 1952.

. The writings of William James - A Comprehensive Edition. Edited by John J. McDermott. Chicago: Chicago University Press, 1977.

KLÜVER, Heinrich. Introduction. In: HAYEK F. A. The Sensory Order. Chicago: The University of Chicago Press, 1952.

KRUEGER, Joel. James on Experience and the Extended Mind. Contemporary Pragmatism. Vol. 3, No. 1, p. 165176, June 2006.

LEVINE, Joseph. Materialism and Qualia: The Explanatory Gap. Pacific Philosophical Quarterly. 64, p. 354-361, 1983.

LEWIS, Clarence. Mind and the World Order. New York: Charles Scribner's Sons, 1990.

MALACHOWSKI, Alan. James's holism: the human continuum. In: (ed.). The Cambridge Companion to Pragmatism. Cambridge: Cambridge University Press, 2013, p. 36-54. 
MANETTI, Giovanni. Philodemus' 'De signis': an important ancient semiotic debate (review article). Semiotica. 138, 1/4, p. 279-297, 2002.

MCDERMOTT, John. J. Introduction. In: (ed.). The writings of William James - A Comprehensive Edition. Edited by John J. McDermott. Chicago: Chicago University Press, 1977, p. xix-1.

MENARY, Richard. The Extended Mind. Cambridge: MIT Press, 2010.

MESLE, C. Robert. Process-Relational Philosophy - An Introduction to Alfred North Whitehead. Conshohocken: Templeton Press, 2008.

MILLER, James G. Living Systems. New York: McGrawHill Book Company, 1978.

NAGEL, Thomas. The view from nowhere. Oxford (USA): Oxford University Press, 1986.

. What is it like to be a bat?. The Philosophical Review, 82, p. 435-450, 1974.

NÖE, Alva. Action in Perception. Cambridge: MIT Press, 2006.

NICHOLSON, Daniel. J. and DUPRÉ, John (Eds). Everything Flows: Towards a Processual Philosophy of Biology. Oxford: Oxford University Press, 2018.

PEIRCE, Charles Sanders. The Collected Papers of Charles Sanders Peirce (CP). Cambridge, MA: Harvard University Press, 1994. 
PETITMENGIN, Claire. Enaction as a Lived Experience towards a Radical Neurophenomenology. Constructivism Foundations, Vol. 12, p. 139-147, 2017.

PICKERING, John. On Whitehead, Embodied Cognition and Biosemiotics. In: WEBER, Michel; D'EPREMESNIL, Diane (ed.). Chromatikon I. Louvain: Press Universitaire de Louvain, 2005, p. 195-215.

PUTNAM, Hilary. Pragmatism - An Open Question. Oxford (UK) and Cambridge (USA), Blackwell, 1995.

Robbins, Philip; Aydede, Murat. A Short Primer on Situated Cognition. In: The Cambridge Handbook of Situated Cognition. Edited by Philip Robbins and Murat Aydede. Cambridge: Cambridge University Press, 2009.

RUSSELL, Bertrand. The Analysis of Matter. London: George Allen \& Unwin, 1954.

RYLE, Gilbert. The Concept of Mind. Oxford: Oxford University Press, 2009.

SCHROEDINGER, Erwin. Mind and Matter In:

What is Life?. Cambridge (UK): Cambridge University Press, 1967, p. 90-165.

SELLARS, Wilfrid. Empiricism and the Philosophy of Mind. Cambridge: Harvard University Press, 1997.

Sensa or sensings: reflections on the ontology of perception. Philosophical Studies, 41, p. 83-111, 1982.

Foundations for a Metaphysics of Pure Process: The Carus Lectures of Wilfrid Sellars. Lecutre I: The Lever of Archimedes: Lecture II Naturalism and Process; e Lecutre 
III: Is Consciousness Physical ? The Monist (Jan. 1981, Vol. 64, No. 1, pp. 3-90).

STENNER, Paul. James and Whitehead: Assemblage and Systematization of a Deeply Empiricist Mosaic Philosophy. European Journal of Pragmatism and American Philosophy, 3(1), p. 101-130, 2011.

TEIXEIRA, Maria Teresa. Ser, Devir e Perecer - a criatividade na filosofia de Whitehead. Lisboa: Centro de Filosofia da Universidade de Lisboa, 2011.

THOM, René. Topological Models in Biology. Topology, Vol. 8, p. 313-335, 1969. 1988.

. Esquissse d'une Sémiophysique. Paris: InterÉditons,

THOMPSON, Evan; STAPLETON, Mog. Making Sense of Sense-Making: Reflections on Enactive and Extended Mind Theories. Topoi, 28, 23-30, 2009.

. Life and mind: from autopoiesis to neurophenomenology. a tribute to Francisco Varela. Phenomenol Cognit Sci 3(4):381-398, 2004.

Mind in life: biology, phenomenology, and the sciences of mind. Cambridge (MA): Harvard University Press, 2007.

VARELA, F.; THOMPSON, E.; ROSCH, E. L'inscription corporelle de l'esprit: sciences cognitives. Paris: Seuil, 1993.

VARELA, Francisco et al. Naturaliser la Phénoménologie - Essais sur la phénoménologie contemporaine et les 
sciences cognitives. Paris: CNRS Édtions, 1999.

VARELA, Francisco. Neurophenomenology: A methodological remedy for the hard problem. Journal of Consciousness studies, 3(4): 330-349, 1996.

WAHL, Jean. Vers le concret - études d'histoire de la philosophie contemporaine: William James, Whitehead, Gabriel Marcel. Paris: J. Vrin, 2004.

WEBER, Michel. The Polysemiality of the Concept of "Pure Experience". An Argumentation for Contiguism Streams of William James, Volume 1, Issue 1, p. 14-16, Spring, 1999.

.Whitehead's Pancreativism. Jamesian Applications. Frankfurt/Paris/Lancaster: Ontos Verlag, Process Thought VIII, 2011.

WEEKES, Anderson. The Mind-Body Problem and Whitehead's Non-reductive Monism. Journal of Consciousness Studies, 19, N. 9-10, 2012.

WHITEHEAD, Alfred. N. Modes of Thought. Cambridge: Cambridge University Press, 1938.

Process and Reality - an essay in cosmology. New York: The Free Press, 1978.

. Science and the modern world. New York: Pelican Mentor Books, 1948. 
